https://dx.doi.org/10.4314/ijs.v23i1.18

Ife Journal of Science vol. 23, no. 1 (2021)

\title{
SYNTHESIS, CHARACTERIZATION AND ANTIBACTERIAL ACTIVITY OF MIXED LIGAND COMPLEXES OF NICOTINAMIDE AND 2,2'-BIPYRIDINE
}

\author{
Akinyele, O. F*., Fakola, E. G., George, R. C. and Durosinmi, L. M. \\ Department of Chemistry, Obafemi Awolowo University, Ile-Ife Nigeria \\ *Corresponding Author: Akinyele, O. F. \\ Email Address: ofakinyele@oauife.edu.ng or ofakins@yahoo.com \\ Received: April 9, 2021; Accepted: April 20, 2021
}

\section{ABSTRACT}

\begin{abstract}
Metal complexes of nicotinamide $\left(\mathrm{L}_{1}\right)$ mixed with 2,2'-bipyridine $\left(\mathrm{L}_{2}\right)$ were synthesized and characterized by solubility studies, magnetic susceptibility, percentage metal analysis, UV-Vis spectroscopy, IR spectroscopy and conductivity measurements. The observed metal analysis were in agreement with the theoretical values. The magnetic susceptibility data showed that all the complexes were paramagnetic with values ranging from 1.50 to 4.92 B.M, except $\left[\mathrm{Zn}(\mathrm{NA})(\mathrm{Bipy}) \mathrm{Cl}_{2} \mathrm{H}_{2} \mathrm{O}\right]$ which is diamagnetic. The conductivity values of $96.20,123.20$ and $130.80 \Omega^{-1} \mathrm{~cm}^{2} \mathrm{~mol}^{-1} \mathrm{Cu}(\mathrm{II}), \mathrm{Co}(\mathrm{II})$ and $\mathrm{Mn}$ (II) complexes respectively reveal their 1:1 electrolytic nature, while $\mathrm{Fe}(\mathrm{III})\left(175.20 \Omega^{-1} \mathrm{~cm}^{2} \mathrm{~mol}^{-1}\right)$ is a $1: 2$ electrolyte, . $\left.\mathrm{Ni}(\mathrm{NA})(\mathrm{Bipy}) \mathrm{Cl}_{2}\right]$ and $\left[\mathrm{Zn}(\mathrm{NA})(\mathrm{Bipy})\left(\mathrm{H}_{2} \mathrm{O}\right) \mathrm{Cl}_{2}\right]$ with conductivity values of 55.70 and $74.40 \Omega^{-1} \mathrm{~cm}^{2} \mathrm{~mol}^{-1}$ are non-electrolytes. The IR spectra showed that nicotinamide in the zinc(II), copper(II), iron(III) and manganese(II) complexes coordinated as an ambidentate ligand through the pyridinic nitrogen, while in the cobalt(II) and nickel(II) complexes, the nicotinamide coordinated through the carbonyl oxygen $(\mathrm{C}=\mathrm{O})$, while the bipyridine bonded to the metals as a bidentate ligand through the pyridinic nitrogen. The antibacterial activities of the ligands and the mixed ligand complexes were screened using the agar diffusion method. The results showed that the mixed ligand complexes displayed higher antimicrobial activity than the free ligands when tested against ten strains of bacteria.
\end{abstract}

Keyword: Nicotinamide, bipyridine, metal complexes, coordination compounds, antibacterial agents

\section{INTRODUCTION}

Nicotinamide also known as 3 pyridinecarboxamide has been known for a very long time, as it is an essential vitamin found in several food products. It is beneficial for several metabolic processes that take place in living organisms aside its status as a necessary dietary supplement. Besides these interesting properties, it has been reported to be used in the treatment of several ailments such as schizophrenia and chronic alcoholism). In fact, the deficiency of nicotinamide leads to a medical condition known as pellagra, which is characterized by dementia, diarrhoea and could result in death.

Metal complexes of several drugs and vitamins have been reported to possess antimicrobial activities, hence the increasing interest in the synthesis, characterization and antimicrobial activities of nicotinamide complexes (Allan et al., 1979; Lawal et al., 2001; A tac et al., 2011; Sahin et al., 2016). The syntheses and structural elucidations of several mixed ligand complexes of nicotinamide have also been reported (Sahin et al., 2016; Cakir et al., 2001; Ucar et al., 2007, Kose , 2007; Al-noor, 2007, Yurdakul et al., 2014). Studies on the antimicrobial activities of the mixed ligand complexes of nicotinamide have shown that the complexes possess higher activity than the free ligands, which is in agreement with numerous reports that have shown that metal complexes of ligands or organic drugs are more active than the free ligands or drugs (Lawal et al., 2015; Akinyele et al., 2020). However, work on the synthesis, structural elucidation and antibacterial activity of $\mathrm{Co}(\mathrm{II}), \mathrm{Ni}(\mathrm{II}), \mathrm{Cu}(\mathrm{II})$, and $\mathrm{Zn}(\mathrm{II}), \mathrm{Fe}(\mathrm{III}), \mathrm{Mn}(\mathrm{II})$ mixed ligand complexes of nicotinamide with 2,2bipyridine has not been reported, this is the essence of this study. The results of this study are herein reported.

\section{EXPERIMENTAL}

All the chemicals and solvents used in the study were obtained from Bond Pharmaceutical and $\mathrm{BDH}$ and were used without further purification. They are nicotinamide, 2,2'-bipyridine, methanol, copper(II) chloride dihydrate, manganese(II) chloride tetrahydrate, iron(III) chloride hexahydrate, cobalt(II) chloride hexahydrate, and nickel(II) chloride hexahydrate. The percentage metal content was determined by complexometric titration using EDTA and atomic absorption 
spectroscopy (AAS). The infrared spectra were recorded in the $4000-400 \mathrm{~cm}^{-1}$ region with a Shimadzu FT-IR 8000 spectrophotometer using $\mathrm{KBr}$ pellets. UV-Visible spectra of the samples were measured in the range $800-200 \mathrm{~nm}$ using a Shimadzu UV-Vis 1800 spectrophotometer. The Magnetic susceptibility measurements were carried out at room temperature using a Sherwood Scientific MXI model Gouy magnetic balance while the melting points of the compounds were determined using a Gallenkamp melting point apparatus, while the conductivity measurement was done by weighing appropriate quantity of the metal complexes on an analytical balance and dissolved in $10 \mathrm{ml}$ of water to get $1 \times 10^{-3} \mathrm{M}$ at $28^{\circ} \mathrm{C}$ solution using HANNA instrument (TDS Conductimeter).

\section{Synthesis of mixed ligand complexes}

Solutions of each of the metal salts $(1.0 \mathrm{mmol}$ of $\mathrm{CoCl}_{2} \cdot 6 \mathrm{H}_{2} \mathrm{O}, \mathrm{CuCl}_{2} \cdot 2 \mathrm{H}_{2} \mathrm{O}, \mathrm{MnCl}_{2} \cdot 4 \mathrm{H}_{2} \mathrm{O}, \mathrm{ZnCl}_{2}$, $\mathrm{NiCl}_{2} \cdot 6 \mathrm{H}_{2} \mathrm{O}, \mathrm{FeCl}_{2} \cdot 4 \mathrm{H}_{2} \mathrm{O}$ ) in $5 \mathrm{ml}$ of methanol was added into stirring homogenous solution of nicotinamide $(0.02 \mathrm{mmol})$ and 2,2'-bipyridine $(0.01 \mathrm{mmol})$ in $10 \mathrm{ml}$ methanol. The solution was stirred for one hour, during which precipitate was formed. The product was filtered, washed with methanol and dried over anhydrous calcium chloride.

\section{Antibacterial Study}

The biological activities of the synthesized ligands and their metal complexes were studied for their antimicrobial activities. Microorganisms used in this study were obtained from culture collections of the Department of Microbiology, Obafemi Awolowo University, Ile-Ife, Osun state, Nigeria. These organisms include typed cultures of National Collection of Industrial Bacteria (NCIB) and locally isolated organism (LIO). The bacterial strains were Bacillus cereus, Staphylococcus aureus, Proteus vulgaris, Vibro fuminisi Clostridium sporogenes, Escherichia coli, Pseudomonas aeruginosa, Pseudomonas flourescens, Klebsiella pneumoniae, Microccus luteus. Nutrient broth (biomark) and nutrient agar (rapid lab) were used for sub-culturing the organisms while Mueller-Hinton agar (LAB M) was used for sensitivity testing. The media were sterilized using autoclave at $121{ }^{\circ} \mathrm{C}$ and $1.05 \mathrm{~kg} / \mathrm{cm}^{3}$ for 15 minutes. The bacterial strains used in the experiment were sub-cultured into nutrient broth and incubated at $37{ }^{\circ} \mathrm{C}$ for 18 hours. The organisms were stored on sterile nutrient agar slants in McCatney bottles and sub-cultured at three months' interval to maintain them for further use. The sensitivity testing of the compounds were determined using agar-well diffusion method. The bacterial strains were first grown in nutrient broth for 18 hours before use. About $0.2 \mathrm{ml}$ of the standardized test isolates (108 $\mathrm{cfu} / \mathrm{ml}$ or $0.5 \mathrm{McF}$ arland standard) was then subcultured into Mueller-Hinton agar (LAB M). Wells were then bored into the agar medium using a sterile $6 \mathrm{~m}$ cork borer. The wells were then filled up with prepared solutions of the complex. Care was taken not to allow solutions to spill on the surface of the medium. The plates were allowed to stand on the laboratory bench for about 1-2 hours to allow for proper in flow of the solution into the medium before incubating the plate in an incubator at $37^{\circ} \mathrm{C}$ for 24 hours. The plates were later observed for zones of inhibition, and the effects of the extract on bacterial strains were compared with that of standard antibiotics, ampicillin.

\section{RESULTS AND DISCUSSION}

The properties of the synthesized compounds including the percentage yields are shown in Table 1. The mixed ligand complexes displayed high melting points and a variety of colours ranging from yellow to lilac except for the zinc complex which was white. The melting point of nicotinamide is $127-129^{\circ} \mathrm{C}$, while the complexes have their melting points above $300{ }^{\circ} \mathrm{C}$, thus the relatively high melting point of the metal complexes suggests high thermal stability.

The theoretical \%metal in the mixed ligand complexes showed good correlation with the experimental values as shown in Table 1 . All the complexes synthesized are soluble in water, while they show varying degrees of solubility in the six common solvents. The solubility of all the complexes in water suggests that they are ionic in nature. 
Table 1: Physical properties and analytical data for compounds

\begin{tabular}{|c|c|c|c|c|c|}
\hline Compound & $\begin{array}{l}\text { Formula (formula } \\
\text { weight) }\end{array}$ & Colour & $\begin{array}{l}\text { Melting } \\
\text { point }\left({ }^{\circ} \mathrm{C}\right)\end{array}$ & $\begin{array}{l}\text { \%metal } \\
\text { found (calc) }\end{array}$ & Yield $(\%)$ \\
\hline Nicotinamide & $\mathrm{C}_{6} \mathrm{H}_{6} \mathrm{~N}_{2} \mathrm{O}(122.125)$ & White & $127-129$ & - & - \\
\hline 2,2'- bipyridine & $\mathrm{C}_{10} \mathrm{H}_{8} \mathrm{~N}_{2}(156.184)$ & White & $70-72$ & - & - \\
\hline$\left[\mathrm{Mn}(\mathrm{NA})(\mathrm{bipy})\left(\mathrm{H}_{2} \mathrm{O}\right)_{2} \mathrm{Cl}\right] \mathrm{Cl}$ & $\begin{array}{l}\mathrm{MnC}_{16} \mathrm{H}_{18} \mathrm{~N}_{4} \mathrm{O}_{3} \mathrm{Cl}_{2} \\
(440.183)\end{array}$ & Yellow & $>350$ & $12.62(12.48)$ & 31.80 \\
\hline$\left[\mathrm{Fe}(\mathrm{NA})(\mathrm{bipy})_{2} \mathrm{Cl} \mathrm{Cl}_{2} \cdot \mathrm{H}_{2} \mathrm{O}\right.$ & $\begin{array}{l}\mathrm{FeC}_{26} \mathrm{H}_{24} \mathrm{~N}_{6} \mathrm{O}_{2} \mathrm{Cl}_{3} \\
(614,712)\end{array}$ & $\begin{array}{l}\text { Deep } \\
\text { Yellow }\end{array}$ & $306-308$ & $9.15(9.08)$ & 60.00 \\
\hline$\left[\mathrm{Co}(\mathrm{NA})(\right.$ bipy $\left.)\left(\mathrm{H}_{2} \mathrm{O}\right)_{2} \mathrm{Cl}\right] \mathrm{Cl}$ & $\begin{array}{l}\mathrm{CoC}_{16} \mathrm{H}_{18} \mathrm{~N}_{4} \mathrm{OCl}_{2} \\
(444.2740)\end{array}$ & Lilac & $316-318$ & $12.90(13.26)$ & 63.07 \\
\hline [Ni(NA)(Bipy) $\left.\left(\mathrm{H}_{2} \mathrm{O}\right) \mathrm{Cl}_{2}\right]$ & $\begin{array}{l}\mathrm{NiC}_{16} \mathrm{H}_{16} \mathrm{~N}_{4} \mathrm{O}_{2} \mathrm{Cl}_{2} \\
(425.923)\end{array}$ & Green & $>350$ & $14.12(13.78)$ & 62.30 \\
\hline$[\mathrm{Cu}(\mathrm{NA})(\mathrm{bipy})(\mathrm{Cl}] \mathrm{Cl}$ & $\begin{array}{l}\mathrm{CuC}_{16} \mathrm{H}_{14} \mathrm{~N}_{4} \mathrm{OCl}_{2} \\
(412.761)\end{array}$ & Blue & $300-302$ & $15.59(15.40)$ & 64.54 \\
\hline$\left[\mathrm{Zn}(\mathrm{NA})(\mathrm{Bipy})\left(\mathrm{H}_{2} \mathrm{O}\right) \mathrm{Cl}_{2}\right]$ & $\begin{array}{l}\mathrm{ZnC}_{16} \mathrm{H}_{16} \mathrm{~N}_{4} \mathrm{O}_{2} \mathrm{Cl}_{2} \\
(432.610)\end{array}$ & White & $>350$ & $15.30(15.11)$ & 78.99 \\
\hline
\end{tabular}

\section{Infrared Spectra}

Table 2 shows the significant absorption bands for both ligands; nicotinamide and 2,2-bipyridine and their $\mathrm{Cu}(\mathrm{II}), \mathrm{Fe}(\mathrm{III}), \mathrm{Mn}(\mathrm{II}), \mathrm{Co}(\mathrm{II}), \mathrm{Zn}(\mathrm{II})$, and $\mathrm{Ni}$ (II) mixed ligand complexes. Bands due to the amido group in the nicotinamide $\left(3368 \mathrm{~cm}^{-1}, 3361\right.$ $\left.\mathrm{cm}^{-1}\right)$, Carbonyl group $\left(1679 \mathrm{~cm}^{-1}\right)$ and C-N (1395 $\mathrm{cm}^{-1}$ ) are displayed in amide complexes, coordination via the amido group and the carbonyl group leads to a negative shift in the frequency of absorption due to a decrease in bond strength of the groups. However, the results showed that there was no coordination via the amido group as the frequency of absorption in all the complexes remained unchanged or showed positive shifts which could be as a result of intramolecular hydrogen bonding and other factors. The inability of the ligand to coordinate to nicotinamide via the amido nitrogen is due to the resonance stabilized nature of amides which accounts for their decreased basicity (Lawal et al., 2015). In the same manner, the absorption bands of the $\mathrm{C}-\mathrm{N}$ remained relatively unchanged.

The absorption bands for the $\mathrm{C}=\mathrm{O}$ showed a negative shift for the cobalt and nickel complexes depicting coordination, however, in the copper complex, there was a positive shift which suggests that no coordination took place via the carbonyl group. The positive shift could be due to combined factors such as intermolecular interactions, the degree of conjugation with the pyridinic nitrogen (Ucar et al., 2007, Lawal et al., 2014). In the remaining complexes, there was a disappearance of the carbonyl group and appearance of a broad O-H group at the highfrequency region, this could be due to the amideamidol tautomerism.

The infrared spectra of the complexes also show positive shifts in the pyridine ring vibration of nicotinamide $\left(1592,1573,1484\right.$ and $\left.995 \mathrm{~cm}^{-1}\right)$ for the $\mathrm{Mn}(\mathrm{II}), \mathrm{Cu}(\mathrm{II}), \mathrm{Ni}(\mathrm{II}), \mathrm{Zn}(\mathrm{II})$ complexes. Positive shifts in the ring vibration of nicotinamide have been reportedly shown to be an evidence of coordination through the pyridine nitrogen of the nicotinamide moiety (Ucar et al., 2007, Lawal et al., 2014). The positive shifts observed for the pyridine ring vibrations arise due to the formation of the M-N (pyridine) bond and changes in the force field (Atac et al., 2011). The positive shifts also served as evidence of coordination of the metal to the two pyridinic nitrogen that occurs in 2,2'-bipyridine although the differences in the shifts were larger.

The appearance of low-intensity bands $415-428$ $\mathrm{cm}^{-1}$ and $576,583 \mathrm{~cm}^{-1}$ in the low-frequency region 
of the spectra strongly suggests coordination, and vibrations. The IR spectra are shown in Figure 1. these bands are attributed to $\mathrm{M}-\mathrm{O}$ and $\mathrm{M}-\mathrm{N}$

Table 2: Some relevant Infrared spectra data $\left(\mathrm{cm}^{1}\right)$ of mixed ligand complexes of nicotinamide

\begin{tabular}{|c|c|c|c|c|c|c|c|}
\hline $\begin{array}{l}\text { Frequency }(v) \\
\text { Compound }\end{array}$ & $\nu_{\mathrm{N}-\mathrm{H}}$ & $\nu_{\mathrm{N}-\mathrm{H}}$ & $\nu_{\mathrm{C}=\mathrm{O}}$ & $\nu_{\text {py(ring) }}$ & $\nu_{\mathrm{C}=\mathrm{N}}$ & $\nu_{\mathrm{M}-\mathrm{O}}$ & $\nu_{\mathrm{M}-\mathrm{N}}$ \\
\hline Nicotinamide (NA) & 3368 & 3361 & 1679 & 1592,995 & 1395 & - & - \\
\hline Bipyridine (bpy) & - & - & - & 1579, 991 & - & - & - \\
\hline$\left[\mathrm{Mn}(\mathrm{NA})(\mathrm{bpy})\left(\mathrm{H}_{2} \mathrm{O}\right)_{2} \mathrm{Cl}\right] \mathrm{Cl}$ & 3440 & - & - & 1574,1017 & - & - & 415 \\
\hline$\left[\mathrm{Fe}(\mathrm{NA})(\mathrm{bpy})_{2} \mathrm{Cl} \mathrm{Cl}_{2} \cdot \mathrm{H}_{2} \mathrm{O}\right.$ & 3437 & - & - & 1563,1026 & - & - & 422 \\
\hline$\left[\mathrm{Co}(\mathrm{NA})(\mathrm{bpy})\left(\mathrm{H}_{2} \mathrm{O}\right)_{2} \mathrm{Cl}\right] \mathrm{Cl}$ & 3405 & 3322 & 1667 & 1481,1049 & 1395 & 583 & 421 \\
\hline$\left[\mathrm{Ni}(\mathrm{NA})(\mathrm{bpy})\left(\mathrm{H}_{2} \mathrm{O}\right) \mathrm{Cl}_{2}\right]$ & 3408 & 3322 & 1670 & 1579,939 & 1397 & 576 & 428 \\
\hline$[\mathrm{Cu}(\mathrm{NA})(\mathrm{bpy})(\mathrm{Cl}] \mathrm{Cl}$ & 3406 & 3163 & 1707 & 1568,1026 & 1379 & - & - \\
\hline$\left[\mathrm{Zn}(\mathrm{NA})(\mathrm{bpy})\left(\mathrm{H}_{2} \mathrm{O}\right) \mathrm{Cl}_{2}\right]$ & 3439 & - & - & 1599,1018 & - & - & 415 \\
\hline
\end{tabular}

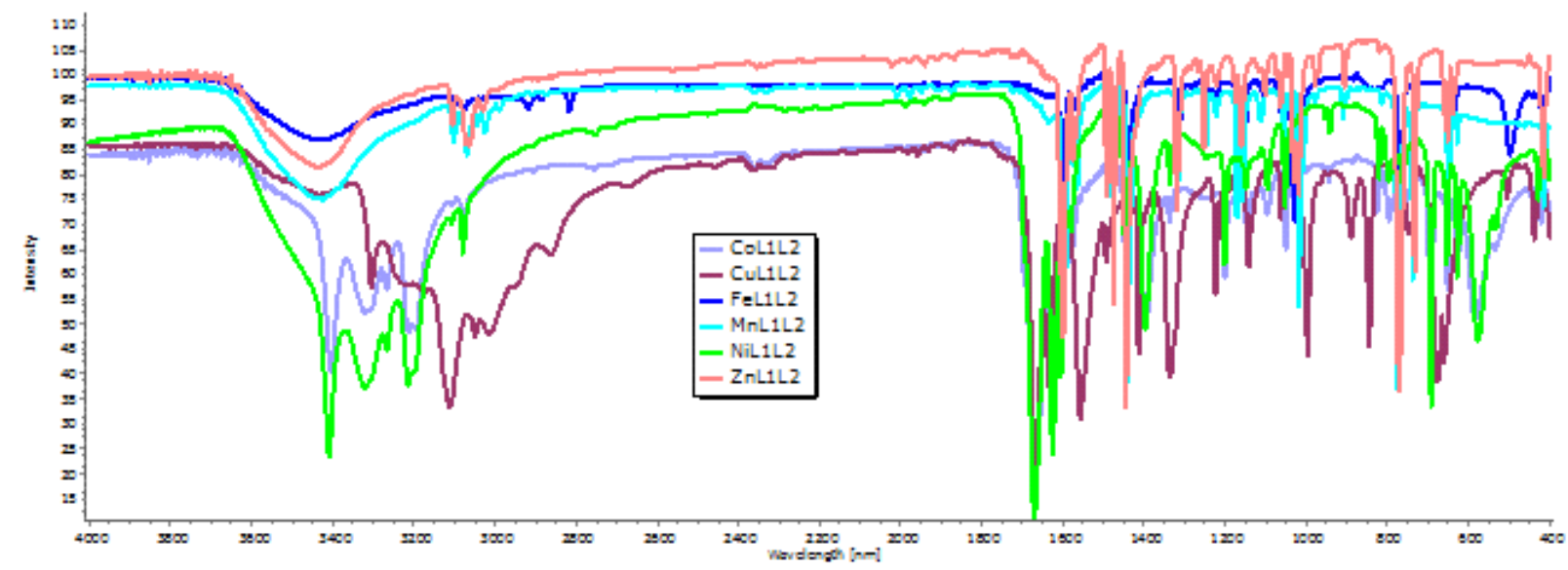

Fig 1: IR spectra of $\mathrm{CoL}_{1} \mathrm{~L}_{2}, \mathrm{CuL}_{1} \mathrm{~L}_{2}, \mathrm{FeL}_{1} \mathrm{~L}_{2}, \mathrm{MnL}_{1} \mathrm{~L}_{2}, \mathrm{NiL}_{1} \mathrm{~L}_{2}, \mathrm{ZnL}_{1} \mathrm{~L}_{2}$

\section{Electronic spectra}

The electronic spectral data measured in water for the synthesized mixed ligand complexes are shown in Table 3.

Upon coordination, the electronic transitions of the complexes exhibited a positive shift toward longer wavelength with values ranging from 264$312 \mathrm{~nm}$ which were due to $\pi-\pi^{*}$ and $\mathrm{n}-\pi^{*}$ transitions (Cakir et al., 2001; Akinyele et al., 2020), which implies a strong interaction between the ligand and the metallic ion. The visible spectra of the Co(II) complex of nicotinamide mixed with 2,2'-bipyridine showed two distinct bands at 509 $\mathrm{nm}$ and $666 \mathrm{~nm}$ which is attributed to ${ }^{4} \mathrm{~T}_{1} \mathrm{~g} \rightarrow{ }^{4} \mathrm{~A}_{1} \mathrm{~g}$ (P) and ${ }^{4} \mathrm{~T}_{1} \mathrm{~g} \rightarrow{ }^{4} \mathrm{~T}_{2} \mathrm{~g}$ in an octahedral environment (Cakir et al., 2001; Kose, 2007). Likewise, the visible spectra of the $\mathrm{Cu}(\mathrm{II})$ complexes showed one band at $737 \mathrm{~nm}$ due to ${ }^{2} \mathrm{~T}_{2} \mathrm{~g} \rightarrow{ }^{2} \mathrm{Eg}$, no distortion was observed in the electronic spectra of $\mathrm{Cu}(\mathrm{II})$ which is consistent for $\mathrm{Cu}$ (II) in a tetrahedral environment (Lee, 1996). The visible spectra of the nickel complexes of nicotinamide with 2,2'-bipyridine showed three bands at 497, $568,677 \mathrm{~nm}$ due to ${ }^{3} \mathrm{~A}_{2} \mathrm{~g} \rightarrow{ }^{3} \mathrm{~T}_{1} \mathrm{~g}(\mathrm{p}),{ }^{3} \mathrm{~A}_{2} \mathrm{~g} \rightarrow{ }^{3} \mathrm{~T}_{1} \mathrm{~g}$ and ${ }^{3} \mathrm{~A}_{2} \mathrm{~g} \rightarrow{ }^{3} \mathrm{~T}_{2} \mathrm{~g}$, as expected for $\mathrm{Ni}$ (II) in an octahedral environment (lee, 1997; Cakir et al., 2001), while the iron (III) complex displayed one band at 480 $\mathrm{nm}$ in the visible region of the spectrum, this is attributed to MLCT since the metal d-orbitals are relatively close in energy to the ligand $\pi^{*}$ orbital in an octahedral field. The Mn(II) complex displayed a weak band at $668 \mathrm{~nm}$ which is attributed to charge transfer transitions in an octahedral environment (Lee, 1996) and these are responsible for their yellowish colour. The zinc complexes of all the complexes only displayed bands within 287 $-312 \mathrm{~nm}$, in the ultraviolet region, there were no 
bands in the visible region as zinc complexes do not produce d-d spectra (Lee, 1996). The electronic spectral data with the assigned transitions are shown in Table 4 while the ultraviolet and the visible spectra of copper, cobalt and manganese mixed nicotinamide and 2,2'-bipyridine complex are displayed in Figures 2a and $2 \mathrm{~b}$ respectively.

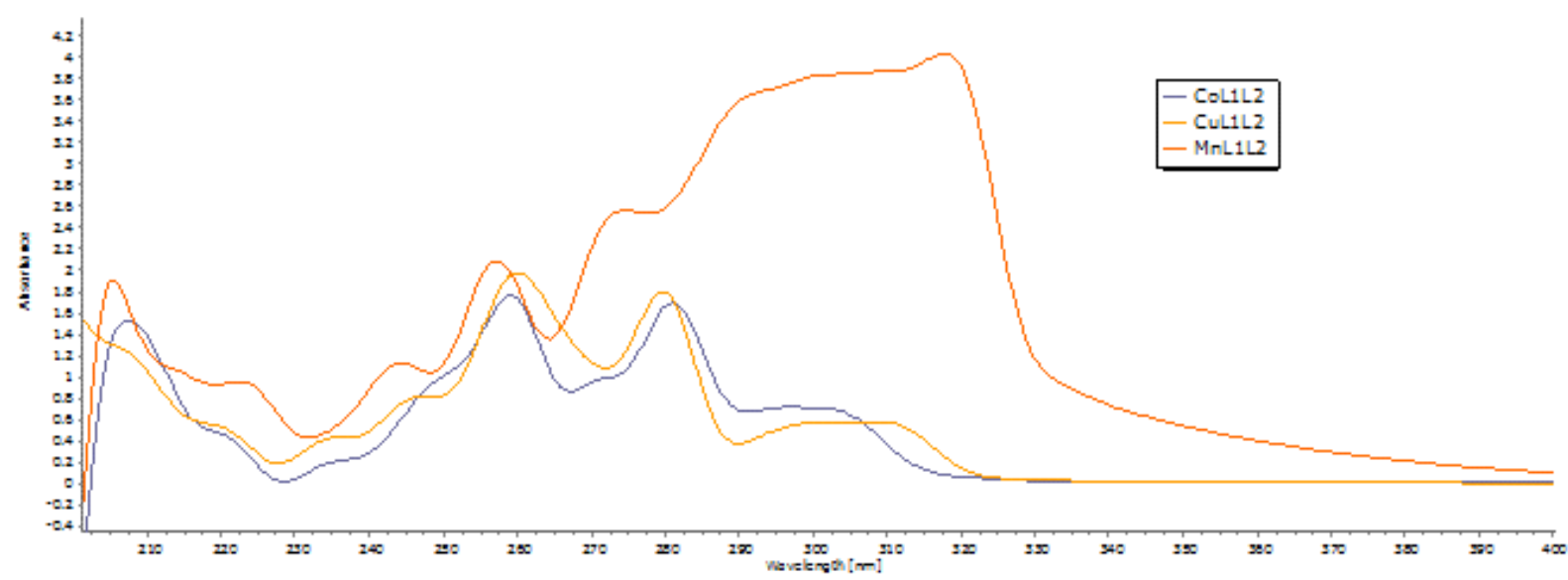

Fig 2a: UV spectra of $\mathrm{CoL}_{1} \mathrm{~L}_{2}, \mathrm{CuL}_{1} \mathrm{~L}_{2}, \mathrm{MnL}_{1} \mathrm{~L}_{2}$

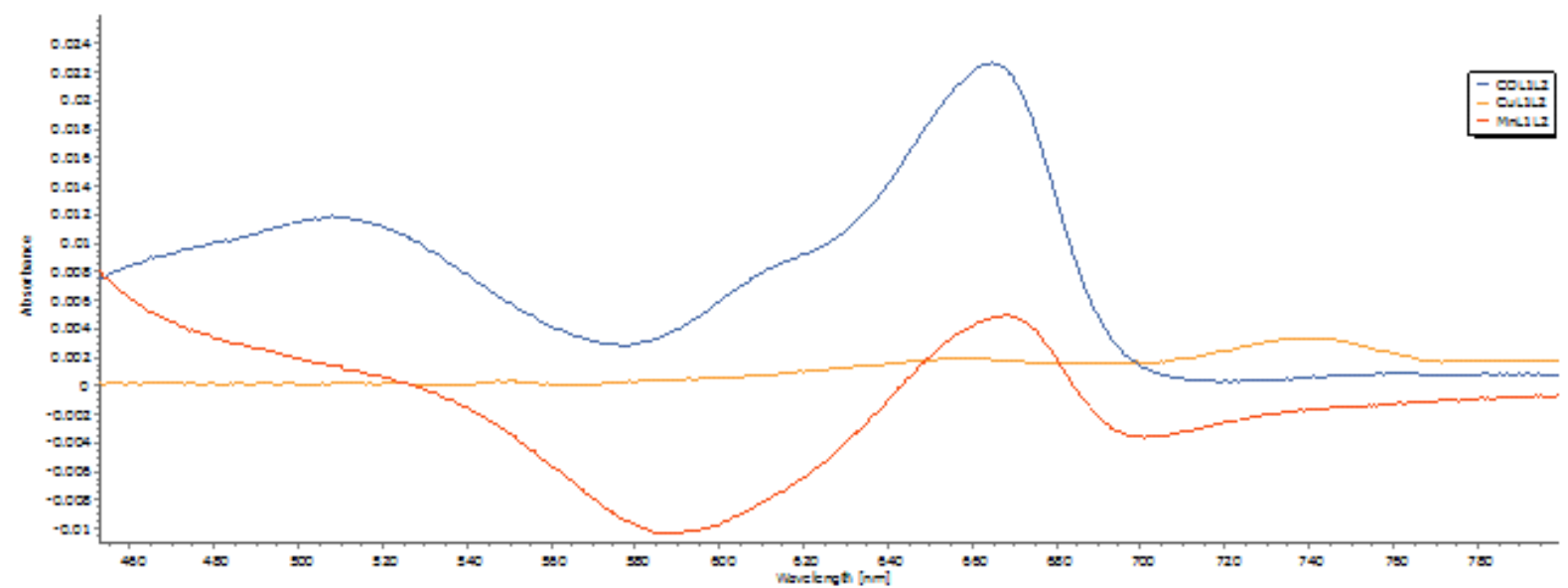

Fig 2b: Visible spectra of $\mathrm{CoL}_{1} \mathrm{~L}_{2}, \mathrm{CuL}_{1} \mathrm{~L}_{2}, \mathrm{MnL}_{1} \mathrm{~L}_{2}$ 
Table 3: Electronic spectra of mixed ligand complexes of nicotinamide and 2,2'-bipyridine

\begin{tabular}{|c|c|c|c|}
\hline Compounds & $\begin{array}{l}\text { Intraligand } \\
\text { transitions (nm) }\end{array}$ & $\begin{array}{l}\text { Ligand field } \\
\text { transitions }\end{array}$ & Assignments \\
\hline Nicotinamide & $\begin{array}{l}215 \\
262\end{array}$ & - & $\begin{array}{l}\pi-\pi^{*} \\
\mathrm{n}-\pi^{*}\end{array}$ \\
\hline 2,2'-Bipyridine & $\begin{array}{l}240 \\
306\end{array}$ & - & $\begin{array}{l}\pi-\pi^{*} \\
\mathrm{n}-\pi^{*}\end{array}$ \\
\hline$\left[\mathrm{Mn}(\mathrm{NA})(\mathrm{Bipy})\left(\mathrm{H}_{2} \mathrm{O}\right)_{2} \mathrm{Cl}\right] \mathrm{Cl}$ & 257,318 & 668 & LMCT \\
\hline$\left[\mathrm{Fe}(\mathrm{NA})(\mathrm{bipy})_{2} \mathrm{Cl} \mathrm{Cl}_{2} \cdot \mathrm{H}_{2} \mathrm{O}\right.$ & 233,281 & 480 & MLCT \\
\hline$\left[\mathrm{Co}(\mathrm{Bipy})(\mathrm{NA})\left(\mathrm{H}_{2} \mathrm{O}\right)_{2} \mathrm{Cl}\right] \cdot \mathrm{Cl}$ & 251,281 & $\begin{array}{l}509 \\
666\end{array}$ & $\begin{array}{l}{ }^{4} \mathrm{~T}_{1} \mathrm{~g} \rightarrow{ }^{4} \mathrm{~A}_{2} \mathrm{~g} \\
{ }^{4} \mathrm{~T}_{1} \mathrm{~g} \rightarrow{ }^{4} \mathrm{~T}_{2} \mathrm{~g}\end{array}$ \\
\hline$\left[\mathrm{Ni}(\mathrm{NA})(\mathrm{Bipy})\left(\mathrm{H}_{2} \mathrm{O}\right) \mathrm{Cl}_{2}\right]$ & 312 & $\begin{array}{l}497 \\
568 \\
677\end{array}$ & $\begin{array}{l}{ }^{3} \mathrm{~A}_{2} \mathrm{~g} \rightarrow{ }^{3} \mathrm{~T}_{1} \mathrm{~g}(\mathrm{P}) \\
{ }^{3} \mathrm{~A}_{2} \mathrm{~g} \rightarrow{ }^{3} \mathrm{~T}_{1} \mathrm{~g}(\mathrm{~F}) \\
{ }^{3} \mathrm{~A}_{2} \mathrm{~g} \rightarrow{ }^{3} \mathrm{~T}_{2} \mathrm{~g}\end{array}$ \\
\hline$[\mathrm{Cu}(\mathrm{NA})(\mathrm{Bipy}) \mathrm{Cl}] \mathrm{Cl}$ & $260,297,307$ & 737 & ${ }^{2} \mathrm{~T}_{2 \mathrm{~g}} \rightarrow{ }^{2} \mathrm{E}_{\mathrm{g}}$ \\
\hline$\left[\mathrm{Zn}(\mathrm{NA})(\mathrm{Bipy})\left(\mathrm{H}_{2} \mathrm{O}\right) \mathrm{Cl}_{2}\right]$ & 308 & - & - \\
\hline
\end{tabular}

\section{Magnetic Moment}

The magnetic moment values as displayed in Table 4 , shows that all the complexes are paramagnetic, except the $\mathrm{Zn}$ (II) complex which was diamagnetic. The copper(II) complex gave a value of $1.5 \mathrm{BM}$ which indicates the presence of antiferromagnetism (Akinyele et al., 2019, Akinyele, 2020). The magnetic susceptibility values for cobalt(II) and $\mathrm{Ni}(\mathrm{II})$ complexes supports an octahedral geometry (Cotton and Wilkinson, 1966; Lee, 1996). The low magnetic moment values displayed by the $\mathrm{Mn}$ (II) complexes is due to antiferromagnetism, which has been reported to be common in their complexes (Lee, 1996). The unusual sub-normal magnetic moment of 3.60 BM observed for Fe(III) complex is as a result of low spin-high spin equilibrium (Garg et al., 1998), hence possesses an ion pair geometry.

The molar conductivity in water of $\mathrm{Cu}(\mathrm{II})$, $\mathrm{Mn}(\mathrm{II}), \mathrm{Co}(\mathrm{II})$ complexes are within the range of $96.20,130.80,123.20 \Omega^{-1} \mathrm{~cm}^{2} \mathrm{~mol}^{-1}$ respectively depicting that they are 1:1 electrolytes while the $\mathrm{Fe}(\mathrm{III})$ complex is a 1:2 electrolyte (Geary, 1971). The molar conductivity of the $\mathrm{Ni}(\mathrm{II})$ and $\mathrm{Zn}(\mathrm{II})$ complexes with values of 55.70 and $74.40 \Omega$ ${ }^{1} \mathrm{~cm}^{2} \mathrm{~mol}^{-1}$ strongly suggests that they are nonelectrolytes indicating that the two chlorides ions are present the coordination sphere. The molar conductivity measurements are presented in Table 4. 
Table 4: Magnetic moment and Conductivity measurements of the complexes at $25^{\circ} \mathrm{C}(298 \mathrm{~K})$

\begin{tabular}{|c|c|c|c|c|}
\hline Compounds & $\begin{array}{c}\text { Molecular } \\
\text { weight } \\
\text { (g/mol) }\end{array}$ & $\begin{array}{c}\mu \text { eff }(\mathrm{BM}) \\
\text { Experimental }\end{array}$ & $\Omega^{-1} \mathrm{~cm}_{2}^{\Lambda \mathrm{mol}}{ }^{-1}$ & Electrolyte \\
\hline$\left[\mathrm{Mn}(\mathrm{NA})(\mathrm{Bipy})\left(\mathrm{H}_{2} \mathrm{O}\right) \mathrm{Cl}\right] \mathrm{Cl}$ & 440.183 & 4.92 & 130.80 & $1: 1$ \\
\hline$\left[\mathrm{Fe}(\mathrm{NA})(\mathrm{bipy})_{2} \mathrm{Cl} \mathrm{Cl}_{2} \cdot \mathrm{H}_{2} \mathrm{O}\right.$ & 614.712 & 3.60 & 175.20 & $1: 2$ \\
\hline$\left[\mathrm{Co}(\mathrm{Bipy})(\mathrm{NA})\left(\mathrm{H}_{2} \mathrm{O}\right) \mathrm{Cl}\right] \mathrm{Cl}$ & 444.178 & 4.0 & 123.20 & $1: 1$ \\
\hline$\left[\mathrm{Ni}(\mathrm{NA})(\mathrm{Bipy})\left(\mathrm{H}_{2} \mathrm{O}\right) \mathrm{Cl}_{2}\right]$ & 425.923 & 2.48 & 55.70 & Non-electrolyte \\
\hline$[\mathrm{Cu}(\mathrm{NA})(\mathrm{Bipy}) \mathrm{Cl}] \mathrm{Cl}$ & 412.761 & 1.50 & 96.20 & $1: 1$ \\
\hline$\left[\mathrm{Zn}(\mathrm{NA})(\mathrm{Bipy})\left(\mathrm{H}_{2} \mathrm{O}\right) \mathrm{Cl}_{2}\right]$ & 432.610 & 0.30 & 74.40 & Non electrolyte \\
\hline
\end{tabular}

\section{Antibacterial activity}

The complexes were tested against ten strains of bacteria consisting of five gram-negative and five gram-positive bacteria. The antibacterial activity was determined using $10 \mathrm{mg} / \mathrm{ml}$ of the synthesized complexes while $1 \mathrm{mg} / \mathrm{ml}$ ampicillin antibiotic was used as the standard. The ligands and their mixed ligand complexes displayed variable ranges of antibacterial activity against the tested bacteria strains. The results revealed that the ligands had low antibacterial activity except for 2,2'-bipyridine which showed relatively good antibacterial activity against the bacterial strains, which could also have accounted for the high activity of the metal complexes.

Generally, the results from the zone of inhibition showed that the metal chelates are more active than the free ligands; this can be attributed to the reduction in the polarity of the metal ion which is a consequence of the partial sharing of its positive charge with the donor groups in the complexes. This results in an increased lipophilicity of the metal complexes which aid their absorption through the lipid bilayer of the selected microorganism (Farrel, 2003; Ali et al., 2012). $\left[\mathrm{Fe}(\mathrm{NA})\left(\right.\right.$ bipy) ${ }_{2} \mathrm{Cl}^{-} \mathrm{Cl}_{2} \mathrm{H}_{2} \mathrm{O}$ had the highest activity against the selected microorganisms some of which were comparable to the activity of the standard drug used i.e. ampicillin except Vibro Fuminisi. This activity could be attributed to the increased lipophilicity of the metal complexes as well as the presence of heterocyclic compounds (Farrel, 2003, Ajayeoba et al., 2017). Table 5 shows the zone of inhibition of the ligand and the mixed ligand complexes.

Table 5: Zone of inhibition of the ligands and mixed ligand complexes

\begin{tabular}{|c|c|c|c|c|c|c|c|c|c|}
\hline $\begin{array}{l}\text { Compounds } \\
\text { Bacteria }\end{array}$ & NA & bpy & $\mathrm{MnL}_{1} \mathrm{~L}_{2}$ & $\mathrm{FeL}_{1} \mathrm{~L}_{2}$ & $\mathrm{CoL}_{1} \mathrm{~L}_{2}$ & $\mathrm{NiL}_{1} \mathrm{~L}_{2}$ & $\mathrm{CuL}_{1} \mathrm{~L}_{2}$ & $\mathrm{ZnL}_{1} \mathrm{~L}_{2}$ & Ampicillin \\
\hline E. Coli & 0 & 14 & 10 & 12 & 20 & 09 & 10 & 10 & 22 \\
\hline C. Sporogenes & 0 & 20 & 12 & 20 & 16 & 18 & 22 & 16 & 0 \\
\hline B. cereus & 0 & 18 & 12 & 20 & 12 & 19 & 20 & 18 & 20 \\
\hline M. Luteus & 0 & 18 & 14 & 10 & 16 & 14 & 20 & 16 & 18 \\
\hline S. aureus & 0 & 20 & 16 & 26 & 20 & 18 & 20 & 19 & 28 \\
\hline V. Fuminisi & 0 & 0 & 0 & 0 & 10 & 0 & 0 & 0 & 0 \\
\hline K. Pnиeomiae & 0 & 22 & 16 & 20 & 18 & 08 & 0 & 08 & 22 \\
\hline P. Fluoresens & 0 & 20 & 10 & 12 & 14 & 10 & 0 & 10 & 24 \\
\hline P. Vulgaris & 0 & 0 & 10 & 12 & 12 & 10 & 0 & 08 & 22 \\
\hline P. aeriginus & 0 & 16 & 12 & 14 & 0 & 12 & 0 & 12 & 18 \\
\hline
\end{tabular}




\section{CONCLUSION}

The synthesis $\mathrm{Cu}(\mathrm{II}), \mathrm{Ni}(\mathrm{II}), \mathrm{Fe}(\mathrm{II}), \mathrm{Co}(\mathrm{II}), \mathrm{Mn}(\mathrm{II})$ and $\mathrm{Zn}$ (II) complexes of nicotinamide mixed with 2,2'-bipyridine and their characterization were carried out via UV-visible, infrared spectroscopy, metal analysis, conductivity and magnetic measurements. The mixed ligand complexes displayed colours ranging from yellow to lilac. The compounds are soluble in water, possess high melting points which depict thermal stability. Infrared spectra show that the nicotinamide acted as an ambidentate ligand bonding via the pyridinic nitrogen in $\mathrm{Mn}, \mathrm{Zn}, \mathrm{Cu}$ and $\mathrm{Fe}$ and and the carbonyl oxygen $(\mathrm{C}=\mathrm{O})$ in nickel and cobalt, while the bipyridine acted as a bidentate ligand. The UV-
Visible spectra in conjunction with the magnetic moments suggested an octahedral geometry for the mixed ligand complexes except for $[\mathrm{Cu}(\mathrm{NA})(\mathrm{bipy})(\mathrm{Cl}] \mathrm{Cl}$ which possessed a tetrahedral geometry. These observations were also supported by the conductivity measurement values. The mixed ligand complexes showed moderate activity against the tested bacteria, with $\left[\mathrm{Fe}(\mathrm{NA})(\text { bipy })_{2} \mathrm{Cl}_{2} \mathrm{Cl}_{2} \mathrm{H}_{2} \mathrm{O}\right.$ having the highest antimicrobial activity which was comparable to that of the standard drug, ampicillin. This could be attributed to increased lipophilicity of the metal complexes and the presence of heterocyclic compounds.

\section{Proposed Structures}

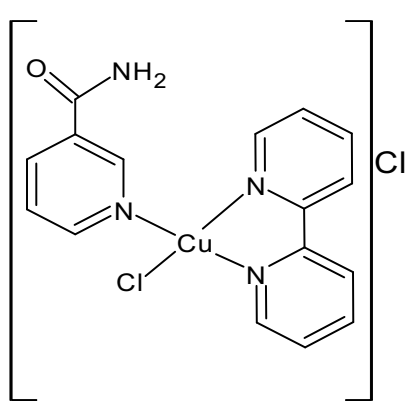<smiles></smiles><smiles></smiles><smiles>NC(=O)c1cccnc1</smiles>

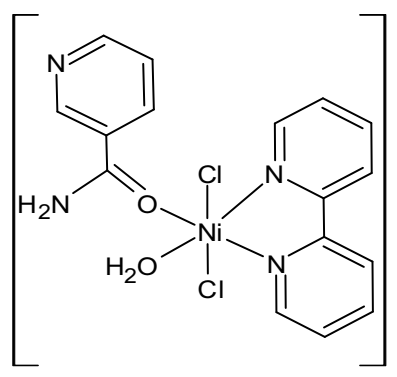<smiles></smiles>

Fig. 3: Proposed Structure for mixed ligand complexes of Nicotinamide and 2,2'-bipyridine

\section{REFERENCES}

Ajayeoba, T. A., Akinyele O. F. and Oluwole. A. O. (2017). Synthesis, characterization and antimicrobial studies of Nickel(II) and Copper(II) complexes of aroylhydrazones with 2,2'-bipyridine and 1,10-Phenanthroline. Ife Journal of Science, 19(1):119-132.

Ali, I., Wani, W. A., Khan, A., Haque, A., Ahmad, A., Saleem, K. and Manzoor, N. (2012). Synthesis and synergistic antifungal activities of a pyrazoline based ligand and its copper(II) and nickel(II) complexes with conventional antifungals. Microbial pathogenesis, 53(2), 66-73.

Al-noor, T. H., Mahmood, A. (2012). Synthesis, Characterization, of mixed ligand Complexes of (Anthranilic Acid and Nicotinamide) with $\mathrm{Mn}(\mathrm{II}), \mathrm{Co}(\mathrm{II})$, $\mathrm{Ni}(\mathrm{II}), \mathrm{Cu}(\mathrm{II}), \mathrm{Zn}(\mathrm{II}) \mathrm{Cd}(\mathrm{II}), \mathrm{Hg}$ (II) and Pd(II) Journal of Kerbala University, 10(2). 114-124.

Allan, J., Baird, N. and Kassyk, A. (1979). Some first row transition metal complexes of 
nicotinamide and nicotinic acid. Journal of Thermal Analysis and Calorimetry, 16(1), 7990.

Akinyele, O. F., Fakola, E. G., Durosinmi, L.M., Ajayeoba, T. A. and Ayeni, A. O. (2020). Synthesis, characterization and antimicrobial activities of heteroleptic metal chelates of isoniazid and 2, 2'bipyridine. Bulletin of the Chemical Society of Ethiopia, 34(3), 471-478.

Akinyele, O. F., Fakola, E. G., Durosinmi, L.M., Ajayeoba, T. A. and Ayeni, A. O. (2019). Synthesis and characterization of heteroleptic metal complexes of Isoniazid and Metformin. Ife Journal of Science, 21(3), 184-192.

Akinyele, O. F., Akinnusi, T. O., Ajayeoba, T. A., Ayeni, A. O. and Durosinmi, L. M. (2019). Synthesis, characterization and antimicrobial activities of Cobalt(II), Nickel(II) and Copper(II) complexes of aroylhydrazone mixed with aspirin. Science Journal of Chemistry, 7(3): 67-71.

Atac, A., Yurdakul, S. and Berber, S. (2011). Synthesis, spectroscopy, and characterization of some bisnicotinamide metal (II) dihalide complexes. Spectrochimica Acta Part A: Molecular and Biomolecular Spectroscopy, 81(1), 684-689.

Bender. D. A. (2003). Niacin. Nutritional Biochemistry of the Vitamins. $2^{\text {nd }}$ Edition, pp 223. Cambridge University.

Cakır, S., Bulut, I., Naumov, P., E. Bice, E. and Çakır, O. (2001). Synthesis and spectroscopic studies of novel $\mathrm{Cu}(\mathrm{II})$, $\mathrm{Co}(\mathrm{II}), \mathrm{Ni}(\mathrm{II})$ and $\mathrm{Zn}(\mathrm{II})$ mixed ligand complexes with saccharin and nicotinamide. Journal of Molecular Structure, $560(1), 1-7$.

Cotton F. A. and Wilkinson G. (1966). Advanced Inorganic Chemistry-A Comprehensive Text (2nd. edition) Interscience. New York, 834-847.

Farrell, N. (2003). Metal complexes as drugs and chemotherapeutic agents. Comprehensive Coordination Chemistry II, 9, 809-840

Garg, B. S., Kurup, M. R. P., Jain, S. K. and Bhoon, Y. K. (1998). Synthesis and Characterization of Iron (III) Complexes of a Substituted 2-Acetyi, Pyridine
Thiosemicarbazone. Synthesis and reactivity in inorganic and metal-organic chemistry, 28(8), 1415-1426.

Geary, W. J. (1971). The use of conductivity measurements in organic solvents for the characterisation of coordination compounds. Coordination Chemistry Reviews, 7(1), 81-122.

Kose. D. A. (2007). Synthesis and characterization of bis(nicotinamide) m-hydroxybenzoate complexes of $\mathrm{Co}(\mathrm{II}), \mathrm{Ni}(\mathrm{II}), \mathrm{Cu}(\mathrm{II})$, and $\mathrm{Zn}(\mathrm{II})$. Russian Journal of Inorganic Chemistry, 52(9), 1384-1390.

Lawal, A., Obaleye, J. A., Adediji, J. F., Amolegbe, S. A., Bamigboye, M. O. and Yunus-Issa, M. T. (2014). Synthesis, Characterization and Antimicrobial Activities of Some Nicotinamide-metal Complexes. Journal of Applied Sciences and Environmental Management, 18(2), 205-208.

Lawal, A., S. Amolegbe, S. A., Rajee, A. O., Babamale, H. F. and Yunus-Issa, M. T. (2015). Synthesis, characterization and antimicrobial activity of mixed ascorbic acid-nicotinamide metal complexes. Bayero Journal of Pure and Applied Sciences, 8(1), 139-142.

Lee, J. D. (1996). Concise Inorganic Chemistry, $5^{\text {th }}$ Edition, 928 - 970. New Delhi, Blackwell Science Ltd, Oxford.

Maurya, R. C., Patel, P. and Sutradhar, D. (2003). Synthesis, magnetic, thermal, and spectral studies of some chelates of $\mathrm{Cu}(\mathrm{II})$, $\mathrm{Ni}(\mathrm{II}), \mathrm{Zn}(\mathrm{II}), \mathrm{Co}(\mathrm{II}), \mathrm{Mn}(\mathrm{II}), \mathrm{Sm}(\mathrm{III})$, and $\mathrm{Th}(\mathrm{IV})$ involving aroylhydrazones derived from isonicotinic acid hydrazide and 2-furyl methyl and 2-thienyl methyl ketone. Synthesis and reactivity in inorganic and metal-organic chemistry, 33(10), $1857-$ 1876.

Osowole, A. A., O. B. Agbaje, O. B. and Ojo, B. O. (2014). Synthesis, characterization and antibacterial properties of some heteroleptic metal(II) complexes of paracetamol and vanillin. Asian Journal of Pharmacentical and Clinical Research,7(3), 145-149.

Rolfe. H. M. (2014). A review of nicotinamide: treatment of skin diseases and potential side effects. Journal of cosmetic dermatology, 13(4), 324-328. 
Sahin, Z. S., Sahin, O. Daglı, O. and Kose, D. A (2016) Diphenic acid/nicotinamide complexes of $\mathrm{Co}(\mathrm{II}), \mathrm{Cu}(\mathrm{II})$ and $\mathrm{Zn}(\mathrm{II})$. Synthesis and structural investigation. Polyhedron, 117, 214-223

Song, S. B., Park, J. S., Chung, G. J., Lee, I. H. and Hwang, E. S. (2019). Diverse therapeutic efficacies and more diverse mechanisms of nicotinamide. Metabolomics, 15(10), 128.

Ucar, I., Bulut, A. Karadag, A. and Kazak, C. (2007). Cobalt dipicolinate complexes with nicotinamide and isonicotinamide ligands: Syntheses, crystal structures, spectroscopic, thermal and voltammetric studies. Journal of Molecular Structure, 837(1), 38-42.

Usman, A. B., Emmanuel, P, and Manchan, D. B. (2019). Pellagra, a re-emerging disease: a case report of a girl from a community ravaged by insurgency. The Pan African Medical Journal, 33.

Yurdakul, O. and Kose, D. A. (2014). Mixed ligand complexes of acesulfame/nicotinamide with earth alkaline metal cations, $\mathrm{Mg}(\mathrm{II})$, $\mathrm{Ca}(\mathrm{II}), \mathrm{Ba}(\mathrm{II})$ and $\mathrm{Sr}(\mathrm{II})$ : synthesis and characterization. Hittite Journal of Science and Engineering, 1(1), 51-57. 